wanted his Chronicon published, and if not, why he wrote the text. The same question applies to the "diary" of Ignatius. Both men felt that these pages testified to the greatest gifts they had received from God, and as such should not be hidden. They were right: "These things were here and but the beholder wanting," as Gerard Manley Hopkins exclaimed in another context (Summer ends now; now, barbarous in...). The Chronicon enables us, as do no other of Nadal's writings, to appreciate Ignatius's right-hand man, who insisted that Ignatius should leave a written record of his inner life. For Nadal that would complete Ignatius's work of "founding" the Society. Ignatius was reluctant because he was aware that spirit, "the interior law of charity and love which the Holy Spirit writes and imprints upon hearts" (Constitutions §134) cannot be captured in words, and it was the spirit he had received and shared that would keep the Society alive.

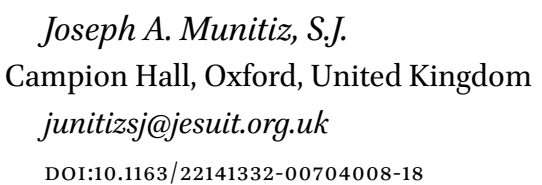

\title{
Luke Murray
}

Jesuit Biblical Studies after Trent: Franciscus Toletus \& Cornelius a Lapide. Refo5oo Academic Studies, 64. Göttingen: Vandenhoeck \& Ruprecht, 2019. Pp. 218. Hb, $€ 80.00$.

This book is the published version of a dissertation directed by Wim François at KU Leuven. The author currently teaches at St. Lawrence Catholic Campus Center, Kansas. The publication of the dissertation is very welcome, since there has been a great void in the study of early Jesuit exegetes (17). The book is structured into four chapters: an introduction to "Jesuit Biblical Studies after Trent" (27-57), two central chapters on Francisco de Toledo (59-104) and Cornelius a Lapide (105-54), and a fourth chapter that analyses and compares the exegesis of John 17:1-12 by both authors as a test case (155-94). The book is framed by a brief introduction (17-25) and "Concluding Remarks" (295-91). The bibliography is divided into primary and secondary sources (203-18). On the whole, the study confirms "that there was a flourishing of Catholic biblical studies after Trent, and the view that humanist studies of Scripture ended with Trent is indeed mistaken" (196).

While Chapter 4 is interesting for the history of the interpretation of John 17 and the theological issues of grace, free will, and predestination, the first three chapters will be useful for a wider readership by laying important groundwork 
for further studies of early modern Jesuit and, more generally, Roman Catholic exegesis. The chapter on "Jesuit Biblical Studies after Trent" is introduced by a bibliographical essay (27-41) and then provides concise summaries of the role of the Council of Trent (41-47), the Jesuit order's rules for exegesis and exegetes (47-53), and the Galileo Affair (53-57). The chapters on Toledo and a Lapide provide summaries of their lives and work before exploring their biblical hermeneutics.

Francisco de Toledo (Franciscus Toletus, 1532-96) came to Rome in 1559, where he taught at the Roman College and became an important advisor to the popes of the period (6o-62). While his philosophical works received far more attention in later reception, he was praised for his biblical expertise during his lifetime (68). The extent to which his biblical work is underexplored is demonstrated by the fact that no more than two publications had analyzed Toledo's hermeneutics: Richard Simon's Histoire critique des principaux commentateurs du Nouveau Testament (Rotterdam, 1693) and Romualdo Galdós's "Méritos escriturísticos del Cardenal Francisco de Toledo S.I." (Archivio teológico granadino 3 [1940]:19-33) (70-72). Murray's explorations of Toledo's theology of inspiration and the nature of Scripture against the background of Aquinas's work and in the context of contemporary theologians are substantial (72-89). Concerning Toledo's concrete biblical hermeneutics (89-104), Murray demonstrates the influence of Spanish humanism (92-93) in Toledo's preference for the literal meaning and his interest in the biblical languages, and helpfully sketches his role in the preparation of the Sixto-Clementine Vulgate (101-4).

Cornelius a Lapide $(1567-1637)$ is generally considered the most outstanding Jesuit exegete of his time, but his extensive work is largely unknown, since it has not been translated from the Latin (108-9). A quiet character, a Lapide became professor of Scripture in Leuven in 1596, and from 1616 dedicated himself to teaching and writing in Rome (105-8). After a survey of literature on a Lapide's hermeneutics (109-29), Murray examines this issue systematically (129-54). A Lapide's conception of inspiration is characterized by the idea of the Holy Spirit's "accommodation" to the human author (133). "In saying that things which the sacred authors 'had seen earlier, or heard, or meditated on' were 'not necessarily inspired or dictated by the Holy Spirit,' a Lapide strongly affirms the natural role or causality of the human author" (134). Concerning a Lapide's understanding of Scripture (135-39), his high level of appreciation for the Old Testament, and his defense of its study are noteworthy (136). A Lapide's hermeneutics is characterized as "prophetic," "pneumatic," and "ecclesial" $\left(153^{-}-54\right)$. In the final evaluation, a Lapide is considered "the superior scholar" 
compared to Toledo, and a "genuine "biblical theologian," while Toledo features as a "scholastic biblical scholar" (201).

The study has a few minor shortcomings. A spell check and thorough proofreading could have avoided some unnecessary mistakes. It is somewhat surprising that no reference is made to the Diccionario histórico de la Compañía de Jesús, 4 vols. (Rome: IHSI, 2001), esp. the entry on "Biblia Sagrada" by Maurice Gilbert (1:437-43). If nothing else, it would have helped to document the scarcity of research. Similarly, reference to Alice L. Laffey's entry on "Biblical Studies" in The Cambridge Encyclopedia of the Jesuits, ed. Thomas Worcester [Cambridge: Cambridge University Press, 2017], 96-101) would only have served the purpose of bibliographical completeness. It could have been interesting, however, to contextualize early modern Jesuit exegesis in the wider realm of early modern reception of the Bible by Jesuits; much relevant material is provided in the multi-authored entry "Jesuit Order" in Encyclopedia of the Bible and Its Reception (Berlin: de Gruyter, 2016), 13:1132-58; this entry, however, significantly lacks a section on Jesuit exegetes.

The dissertation's supervisor, who contributed a preface (9-10), considers "one of the most interesting findings" of the dissertation "the link between the theory of biblical inspiration, on the one hand, and that of predestination, grace, and freewill, on the other. Authors who tend to emphasize the role of God's grace in the process of salvation (and minimize man's contribution) are inclined to accept that the Bible is a book largely dictated by God. Authors who are prepared to accept a large part of the human person's contribution in the process of salvation, equally agree upon more participation of the human authors in the coming into being of the biblical texts" (9-10). This theologically interesting point certainly deserves further exploration. It mirrors the dissertation's predominant interest in framing early modern exegesis in the terms of the history of theology. Its potential interest for contemporary exegetes, especially now that they have become more aware of the relevance of the history of interpretation and reception, still deserves exploration. Murray's book provides important groundwork for the study of widely neglected, but towering figures of early modern exegesis. It is to be hoped, therefore, that it marks the beginning of further, more extensive, and profound research.

\section{Dominik Markl, S.J.}

Pontifical Biblical Institute, Rome, Italy

markl@biblico.it

DOI:10.1163/22141332-00704008-19 